\title{
Relation between student's perceptions to the statistics lecturer in learning process with statistics achievement
}

\author{
A. Muhajir Nasir ${ }^{a^{*}}$, Dian Hardianti Hasmar ${ }^{\mathrm{b}}$ \\ ${ }^{a}$ Department of Mathematics Education, Universitas Muslim Maros, Maros, Indonesia, 90511 \\ ${ }^{\mathrm{b}}$ MTs. Negeri 2 Jeneponto, Jeneponto, Indonesia, 92371 \\ *Corresponding author: muhajirnasir@gmail.com
}

\section{ARTICLE HISTORY}

Received April 2, 2018

Revised May 12, 2018

Accepted June 20, 2018

\section{KEYWORDS}

Student's perception

Statistics achievement

Descriptive and inferential statistics

\begin{abstract}
This is ex post facto research to find the relation between student's perceptions to the statistics lecturer in learning process with statistics achievement of students semester $\mathrm{V}$ of the Department of Mathematics Education of Universitas Muslim Maros. The population is all students of the Department of Mathematics Education Universitas Muslim Maros in academic year $2017 / 2018$. And the sample is 30 respondents of students who taught by statistics lecturer. Data analyze by SPSS software. According to analyze get that student's perception to statistics lecturer generally very positive with average 138,57 and statistics achievement is very good with average 79,63 . Besides that, inferential show that there is relation between student's perceptions to the statistics lecturer with coefficient is 0,594 . From analyze, it can conclude that there are relation between student's perceptions to the statistics lecturer in learning process with statistics achievement of students semester V of Department of Mathematics Education Universitas Muslim Maros.
\end{abstract}

This is an open access article under the CC-BY-SA license.

\section{INTRODUCTION}

One of the important figure in university is lecturer. Lecturer represents the key person in class. Lecturer leading and instructing activity of student study. Lecturer has most relating to student compared to the other personnel. For student, lecturer is somebody owning authority, not only authority in academic but also in nonacademic. In society, lecturer performance as a model. Lecturer as counselor and instructor in learning.

Based on the result of observation, statistics achievement of student of mathematics education of Universitas Muslim Maros is low. This matter visible from average of daily restating grade, mid of semester and general examination of mathematics lecture for student at this university. Based on result interview, most students open the opinion that the ways of teaching of all lecturers are different so that it causing the happening of degradation results of learning.

Students represent the social and individual creature. As individual creature, each student has a lot of difference. These differences cause the view, opinion and student assessment to lecturer in learning are different each other. Therefore, there are different ideas from each student that writer interview. Some student confess prefer to lecturer so that diligent to follow the subject but there are also student confessing to become lazy follow the lecturer subject because they are not interesting to the lecturer.

Based of the problems above, the researcher want to do research with the title "Relation between Student's Perceptions to the Statistics Lecturer in Learning Process with Statistics
Achievement of Students".

Based on the background, problem statements that will be research are:

1. How about perception of students semester $\mathrm{V}$ of Mathematics Education Universitas Muslim Maros to the statistics lecturer?

2. How high of statistics achievement of students semester V of Mathematics Education Universitas Muslim Maros?

3. Are there positive relations between student's perception to the statistics lecturer in learning process with statistics achievement of students semester $\mathrm{V}$ of Mathematics Education Universitas Muslim Maros?

\section{METHOD}

This research is ex post facto, it means from what is done afterwards'. In the context of social and educational phrase means 'after the fact' or retrospectively' and refers to those studies which investigate possible cause and effect relationships by observing an existing conditions or state of affair and searching back in time for plausible causal factors.

In this research, there are two variable that are student's perception to the lecturer in learning process as independent and statistics achievement of student semester $\mathrm{V}$ of the Department of Mathematics Education of Universitas Muslim Maros as dependent variable.

According to Cohen (2000), we earlier referred to the two basic designs embraced by ex post facto research, the co-relational (or causal comparative) models. We return to them 
again here in order to consider designing both typed of investigation. As we saw, the causal model attempts to identify the antecedents of the present condition and may be representing thus:

\section{$\mathrm{X} \longrightarrow \mathrm{Y}$}

Fig 1. Relation between two variables

Where:

$\mathrm{X}=$ student's perception to the lecturer in learning process

$\mathrm{Y}=$ statistics achievement of student semester $\mathrm{V}$ of the

mathematics education at Universitas Muslim Maros

This research is doing at Universitas Muslim Maros, District Maros Sulawesi Selatan. It was doing after final test at semester $\mathrm{V}$ in academic year $2017 / 2018$. This research starts by pra-survey on July until December 2017 and collecting data on January until February 2018.

Subject of this research are students of the Department of Mathematics Education of Universitas Muslim Maros who follow the final examination of statistics subject in academic year $2017 / 2018$. The objects are questioner and statistics test achievement.

Student's perception to the lecturer in learning process is response of student semester $\mathrm{V}$ of the Department of Mathematics Education of Universitas Muslim Maros to lecturer performance in knowledge, skill, and attitude that shown in learning process with indicator:

1. Cognitive flexibility of lecturer

a. lecturer cognitive to student

b. lecturer cognitive to subject matter of statics

2. Openness of lecturer psychologist

a. Ability to communicate

b. Emphatic

3. Personal behavior
a. Patient
b. Honesty
c. Humorist
d. Friendly

Therefore, statistics achievement is test score that achieve from statistics test achievement in cognitive.

In this research, there are two instruments, which are (1) questioner, and (2) test achievement. of statistics. To measure student's perception to the lecturer in learning process, researcher use questioner that consist of scale of statement as perception to the lecturer in learning process. To measure statistics achievement, by using test of statistics achievement about statistics problem. Both of them give to the students directly and then filling and doing by them.

Questioner using to collect data from independent variable and statics achievement using to collect data of dependent variable. Data that got from respondent as a primer data. Result from filling the questioner then scoring by scoring procedure to change likert scale to become interval scale. These final score can be data of research for independent variable. While statics achievement test scoring as data of dependent variable.

This research uses two statistic techniques to analyze the data that are descriptive statistic and inferential statistic. Descriptive analyze for data of student's perception to the lecturer which are deviation standard, maximum, minimum and getting characteristic of data in this research.
For classification of statics achievement of students using classification with 5 scales, which are:

Table 1. Classification Students Achievement

\begin{tabular}{cc}
\hline Interval & Classification \\
\hline $81-100$ & Very Good \\
\hline $61-80$ & Good \\
\hline $41-60$ & Average \\
\hline $21-40$ & Poor \\
\hline $0-20$ & Very Poor \\
\hline
\end{tabular}

For Inferential, suitable to the aim of research, that is to know the relation between independent variable (student's perception) and dependent variable (statics achievement of students), so that inferential statistic which use is correlation of product moment analysis. Hypothesis test by using SPSS software.

\section{RESULTS AND DISCUSSION}

\subsection{Descriptive Statistics Analysis}

Finding of analyze data by descriptive statistic shown description of data in table and histogram.

\section{Student's perception to the lecturer in learning process}

Results of descriptive analyze which relate with score of independent variable (student's perception) shown in table:

Table 2. Descriptive statistics for student's perception

\begin{tabular}{lc}
\hline \multicolumn{1}{c}{ Statistics } & Student's perception \\
\hline $\mathrm{N}$ & 30 \\
\hline Minimum & 100 \\
\hline Maksimum & 164 \\
\hline Mean & 138,57 \\
\hline Standar Deviasi & 17,534 \\
\hline
\end{tabular}

From table 2 known that average score is 138,57 with deviation standard is 17,534 . It means that there are not data out of other data because deviation standard less than average score. Classifications of student's perception shown in table 3 .

Table 3. List of score student's perception

\begin{tabular}{cccc}
\hline Interval $(\%)$ & Classification & Frequency & Percentage \\
\hline $81-100$ & Very Positive & 18 & 60 \\
\hline $61-80$ & Positive & 9 & 30 \\
\hline $41-60$ & Neutral & 3 & 10 \\
\hline $21-40$ & Negative & 0 & 0 \\
\hline $0-20$ & Very Negative & 0 & 0 \\
\hline & Total & 30 & 100 \\
\hline
\end{tabular}

According to score category of perception table above, known that generally perception of students semester $\mathrm{V}$ of Mathematics Education of Universitas Muslim Maros to lecturer is very positive with percentage is $60 \%$ (18 of 30 respondents).

Next, frequency distribution of student's perception is shown on graph as follow: 


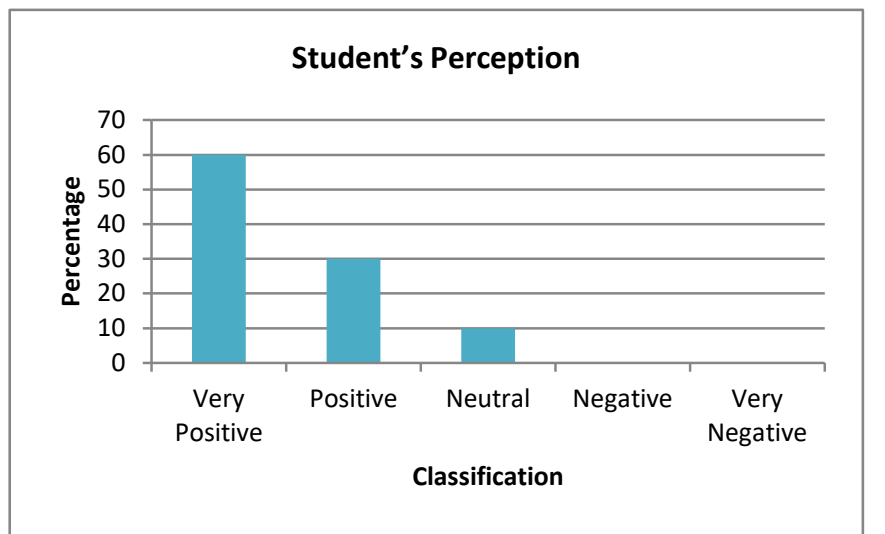

Fig 2. Histogram of frequency distribution of perception

Results of descriptive analyze which relate with score of dependent variable (statistic's achievement) shown in table.

Table 4. Descriptive statistic for statistics achievement

\begin{tabular}{lc}
\hline \multicolumn{1}{c}{ Statistics } & Student's Perception \\
\hline $\mathrm{N}$ & 30 \\
\hline Minimum & 58 \\
\hline Maksimum & 91 \\
\hline Mean & 79,63 \\
\hline Standar Deviasi & 8,755 \\
\hline
\end{tabular}

From table 4 known that average score is 79,63 with deviation standard for 8,755 . It means that there are not data out of other data because deviation standard less than average score. Classification of statistics achievement shown in table 5 .

Table 5. List of statistics achievement

\begin{tabular}{cccc}
\hline Interval $(\%)$ & Classification & Frequency & Percentage \\
\hline $81-100$ & Very Good & 15 & 50 \\
\hline $61-80$ & Good & 12 & 40 \\
\hline $41-60$ & Average & 3 & 10 \\
\hline $21-40$ & Poor & 0 & 0 \\
\hline $0-20$ & Very Poor & 0 & 0 \\
\hline \multicolumn{5}{c}{ Total } & 30 & 100 \\
\hline
\end{tabular}

According to score category of statistics achievement above, known statistics achievement of students semester $\mathrm{V}$ of Mathematics Education of Universitas Muslim Maros are very good with percentage $50 \%$ (15 of 30 respondents). Furthermore, classification of statistics achievement of students who taught by lecturer shown in graph as following.

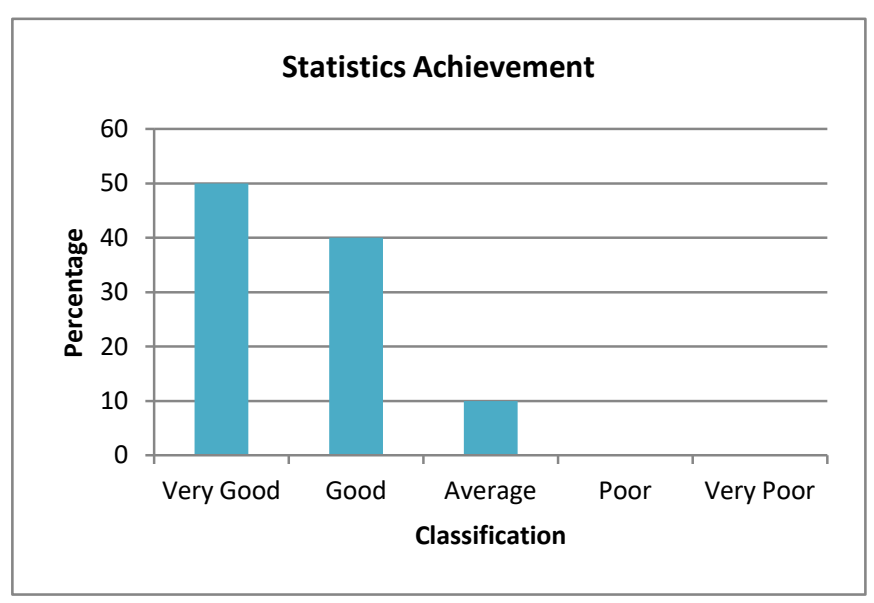

Fig 3. Histogram of frequency distribution statistics achievement

\subsection{Inferential Statistics Analysis}

Inferential statistic present pre requites, that are normality test and linearity test and then result of hypothesis test.

\section{Normality test}

Normality test to student's perception shown that significant value is $0,728>\alpha=0,05$, it means that data perception of students semester $\mathrm{V}$ of Mathematics Education Universitas Muslim Maros is normal.

Normality test to statistics achievement of student shown that significant value is $0,676>\alpha=0.05$, it means that data of statistics achievement of student semester $\mathrm{V}$ of Mathematics Education Universitas Muslim Maros is normal.

\section{Linearity test}

Independent and dependent variable is linear if level of significance less than probability $(p<0,05)$. Linearity test of relation between student's perception to the statistics lecturer in learning process with statistics achievement of students semester $\mathrm{V}$ of Mathematics Education Universitas Muslim Maros shown that $F_{\text {linierity }}$ is 20,333 with level of significance Flinierity is $0,003(p<0,05)$, it means relation is linear.

Equation of regression that used is simple equation of regression that is $Y^{\prime}=a+b X$, where $a=38,535$ and $b=0,297$, hence equation of regression $Y^{\prime}=38,535+0,297 X$.

\section{Hypothesis Test}

Ho : there is no relation between student's perceptions to the lecturer in learning with statics achievement of students semester $\mathrm{V}$ of Mathematics Education of Universitas Muslim Maros

Ha: there are relation between student's perception to the lecturer in learning and process with statics achievement of students semester $\mathrm{V}$ of Mathematics Education Universitas Muslim Maros

Based on correlation analyze by SPSS software, coefficient of correlation $r_{\text {cal }}$ is 0,594 . If compare with $r_{\text {table }}$ with $N=30$ in level of significance 0,05 is 0,349 . It coefficient have sufficient correlation. It shown that $r_{\text {cal }}>r_{\text {table }}$, hence Ho is dishonor and Ha accepted. Thereby there are relations between student's perceptions to the lecturer in learning process with statics achievement of students semester V of Mathematics Education of Universitas Muslim Maros.

From analyze, known that determination coefficient is 0,353 , it means that affectation of variable student's perception to lecturer is $35,3 \%$ and $64,7 \%$ affected by another variable.

Equation of regression that used is simple equation of regression that is, $a=38,535$ and $b=0,297$, hence equation of regression $Y^{\prime}=38,535+0,297 X$.

Coefficient $b$ explains direction of change average of statics achievement for each alteration of variable student's perception. Its alteration is increase if value $b$ is positive and decrease if $b$ negative. From analyze, getting $b$ positive, it means that every variable of student's perception increase one, average of variable statics achievement of students semester $\mathrm{V}$ of Mathematics education at Universitas Muslim Maros increase 0,297 . 


\subsection{Discussion}

Based on analyze by descriptive statistic can explain that generally students semester $\mathrm{V}$ of Mathematics education at Universitas Muslim Maros have positive perception. So do statics achievement of students. Generally, statics achievements of students are good.

After analyze the data by inferential statistic for research about relation between student's perceptions to the lecturer in learning process with statics achievement of students semester $\mathrm{V}$ of Mathematics education at Universitas Muslim Maros with coefficient rcal is 0,594. It shown that there are relations between student's perceptions to the lecturer in learning process with statics achievement of students semester $\mathrm{V}$ of Mathematics education at Universitas Muslim Maros. But then, it appertained in sufficient correlation. Besides it, getting coefficient determination 0,353 means that affectation of variable student's perception to teacher has certified is $35,3 \%$. Whereas $64,7 \%$ affected by another by another variable.

Equation of regression that used is simple equation of regression that is, $=38,535$ and $b=0,297$, hence equation of regression $Y^{\prime}=38,535+0,297 \mathrm{X}$.

Its alteration is increase if value $b$ is positive and decrease if $b$ negative. From analyze, getting $b$ positive. Coefficient $b$ explains direction of change average of statics achievement for each alteration of variable student's perception. From analyze the value $b$ is 0,297 (positive) its alteration is increase. It means that there are positive relations between student's perceptions to the lecturer in learning process with statics achievement of students semester $\mathrm{V}$ of Mathematics education at Universitas Muslim Maros. From analyze, it means that every variable student's perception increase one, average of variable statics achievement of students semester V of Mathematics education at Universitas Muslim Maros increase 0,297.

From this finding, in shown that if lecturers have cognitive, openness psychology, and good behavior, will be effective influence the student included statics achievement. This finding analogous with explanation of Slameto (in Nugrahani, 2010), pass through of good relation between lecturer and students, students will be loved their lecturer and then will be loved their subject that lecturer gave until the students try to learn of it as well as possible. The other way, if students abhor their lecturer, then they will be reluctant to learn the lesson that lecturer gave.

This finding supported too by Astuti (2010) that shown that positive perception can see from positive cognitive assessment and opinion of students to their lecturer. Cognitive and opinion aspect of students is a very important thing. When the students doing something with comfortable, hence given positive impact. Sympathy not occurs from rational logic, but based on opinion like identification process. Interesting to lecturer behavior will be motivated students to more understanding and make good relation until can occur cooperative with their lecturer.

\section{CONCLUSION}

According to finding, conclusions of this research are: (1) Generally perception of students semester V of the Department of Mathematics Education at Universitas Muslim Maros are very positive, (2) Generally statics achievement of students semester $\mathrm{V}$ of the Department of Mathematics education at Universitas Muslim Maros are very good, (3) There are positive relations between student's perception to the lecturer in learning process with statics achievement of students semester $\mathrm{V}$ of mathematics education at Universitas Muslim Maros.

\section{REFERENCES}

Akhmadi, A.N., Qurohman, M.T. and Syarifudin, S. (2017). Peningkatan Kompetensi Auto CAD Bagi Siswa SMK Ma'arif NU Talang Kabupaten Tegal. Jurnal Pengabdian Masyarakat Progresif Humanis Brainstorming, 1(1).

Astuti, Anik Wahyu. (2009). Motivasi Berprestasi Ditinjau dari Persepsi terhadap Kompetensi Guru pada Siswa Kelas XI dan XII Program RSBI (Rintisan Sekolah Bertaraf Internasional) Di SMA Negeri 1 Purworejo. Skripsi. Semarang: Universitas Diponegoro.

Bakkidu, Nurhindah. (2007). Strategi Pembelajaran. Makassar: CV. Samudra Alif-MIM.

Cohen, Louis. (2005). Research Methods In Education. New York: Routledge Falmer Taylor \& Francis Group.

Faisal, Sanapiah. (1982). Metodologi Penelitian Pendidikan. Surabaya: Usaha Nasional.

Fonna, M., \& Mursalin, M. (2018). Role of Self-Efficacy Toward Students' Achievement in Mathematical Multiple Representation Ability (MMRA). Jurnal Ilmiah Peuradeun, 6(1), 31-40.

Irianto, Agus. (2009). Statistik: Konsep Dasar dan Aplikasinya. Jakarta: Kencana Prenada Media Group.

Nasir, A. Muhajir. (2016). Statistik Pendidikan. Yogyakarta: Media Akademi.

Nasir, A. Muhajir. (2017). Pengembangan Perangkat Pembelajaran Model Pengajaran Langsung yang Melibatkan Media Animasi. Jurnal Kompetensi, 11(1), 1-10.

Norton, Lin S. (2009). Action Research in Learning and Teaching. New York: Routledge Falmer Taylor \& Francis Group.

Nugrahani, Udyaksa Pratista. (2010). Hubungan antara Persepsi terhadap Tugas Akademik dan Atraksi Interpersonal Siswa Terhadap Guru Dengan Motivasi Belajar Pada Siswa Program Rintisan Sekolah Bertaraf Internasional (SMA Negeri 7 Purworejo). Skripsi. Semarang: Universitas Diponegoro.

Priyatno, Duwi. (2010). Paham Analisa Statistik dengan SPSS. Jakarta: PT. Buku Seru.

Qurohman, M.T. (2017). Analisis Perangkat Pembelajaran Group Investigation Berbasis RME untuk Meningkatkan Kemampuan Pemecahan Masalah Materi Kalkulus. In Prosiding 2nd Seminar Nasional IPTEK Terapan (SENIT) 2017 (Vol. 2, No. 1, pp. 156-161).

Rudiyanto, Teguh. (2006). Persepsi siswa SMK Panca Bhakti Banjarnegara Terhadap pelajaran pendidikan jasmani. Skripsi. Semarang: Universitas Diponegoro.

Salvin, Robert. (2000). Educational Physiology. United Stated of America: Library of Congress Cataloging in Publication Data.

Sandjaja \& Heryanto. (2006). Panduan Penelitian. Jakarata: Prestasi Pustaka Publisher.

Sudijono, Anas. (1996). Pengantar Evaluasi Pendidikan. Jakarta: PT. Raja Grafindo Persada.

Sugiyono. (1997). Statistika untuk Penelitian. Bandung: Alfabeta.

Susilana, Rudi. Riyani. (2007). Media Pembelajaran. Bandung: CV. Wacana Prima.

Tiro, Muhammad Arif. (2000). Statistika Dasar. Makassar: State University of Makassar Press.

Westwood, Peter S. (2008). Teaching Method. Camberwell. Vic.: ACER Press.

License information: This is an open-access article distributed under the terms of the Creative Commons Attribution License, which permits unrestricted use, distribution, and reproduction in any medium, provided the original work is properly cited. 